\title{
Kyphoscoliosis: looking beyond the spine
}

\author{
Joana Fonseca Ferreira, Margarida Coutinho, Cátia Duarte, José da Silva
}

Rheumatology Unit, Centro Hospitalar e Universitário de Coimbra, Coimbra, Portugal

\section{Correspondence to}

Dr Joana Fonseca Ferreira, joana.fonseca.ferreira@gmail. com

Accepted 13 February 2015

\section{DESCRIPTION}

A 38-year-old woman was referred to the rheumatology department due to mechanical low back pain and progressive scoliosis that started in adolescence. She had no other joint or systemic symptoms despite pigmented skin lesions scattered throughout the body.

The physical examination revealed severe dorsal kyphosis associated with structural lumbar scoliosis and numerous 'café-au-lait' lesions (figure 1) spread over the skin, freckling in the arm pits and inguinal folds (figure 2). The radiographs revealed spinal misalignment, without fractures or lytic lesions. No relevant changes were observed in laboratory tests (figure 3).

A diagnosis of neurofibromatosis type 1 (NF1) was established. ${ }^{1}$ Genetic testing revealed a mutation on NF1 gene, confirming the diagnosis.

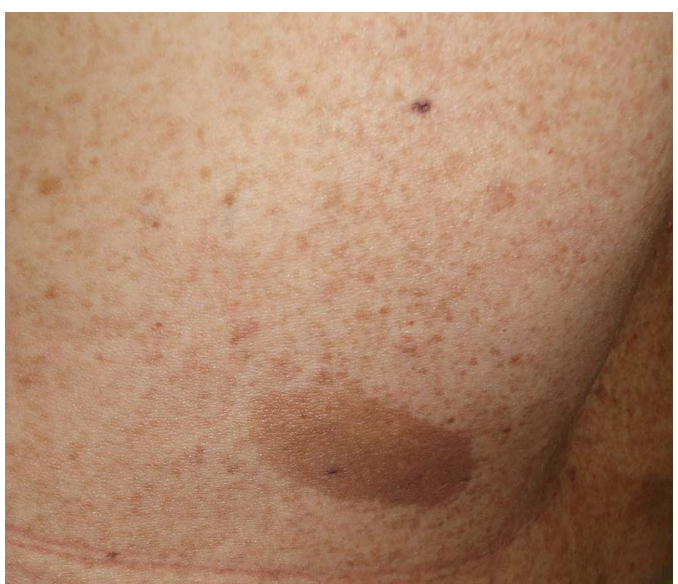

Figure 1 Dorsal 'cafe-au-lait' skin lesion.
One year later, the patient presented with persistent frontal headache, resistant to acetaminophen and non-steroidal anti-inflammatory drugs. A cranial CT scan revealed bilateral thickened optic nerves, suggesting optic gliomas (figure 4), a hallmark of this disease.

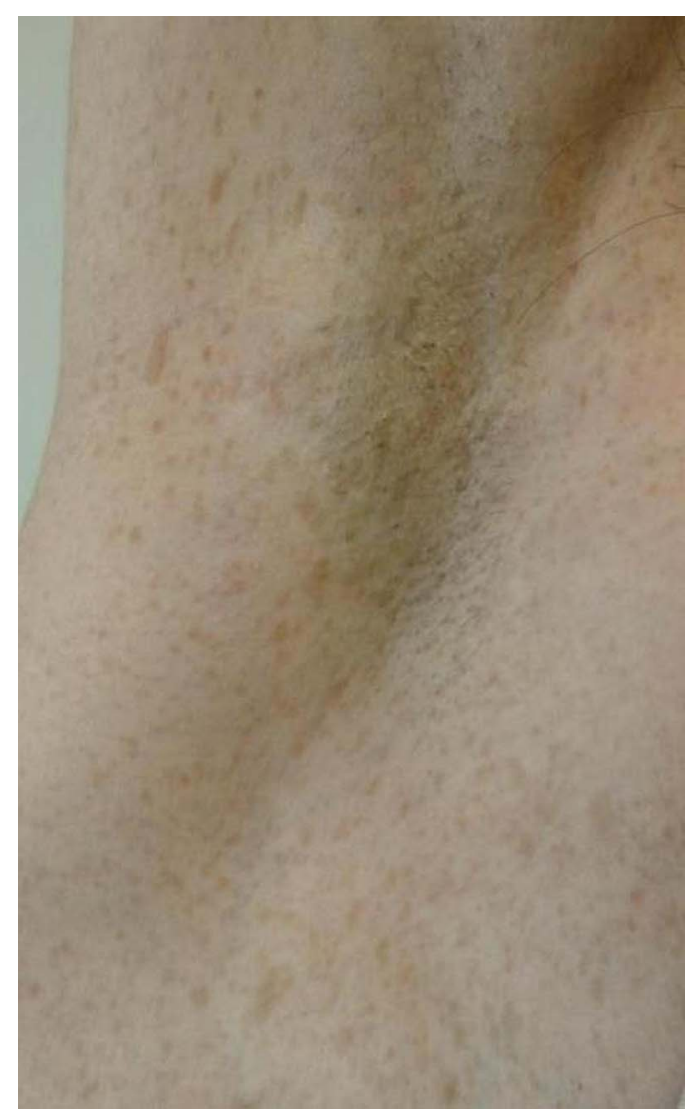

Figure 2 Armpit lesions: axillary freckling. 


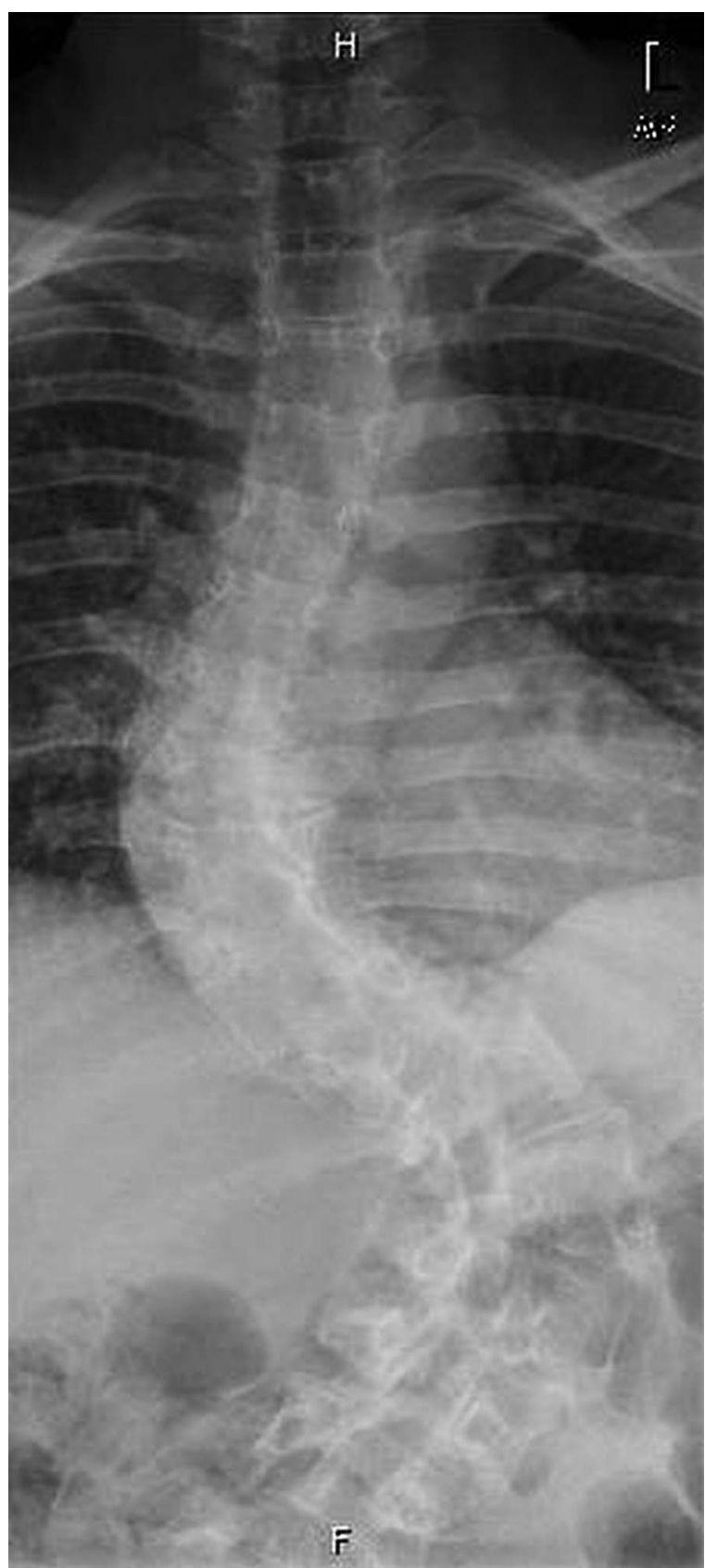

Figure 3 Anteroposterior X-ray exhibiting an exuberant dorsolumbar scoliosis.

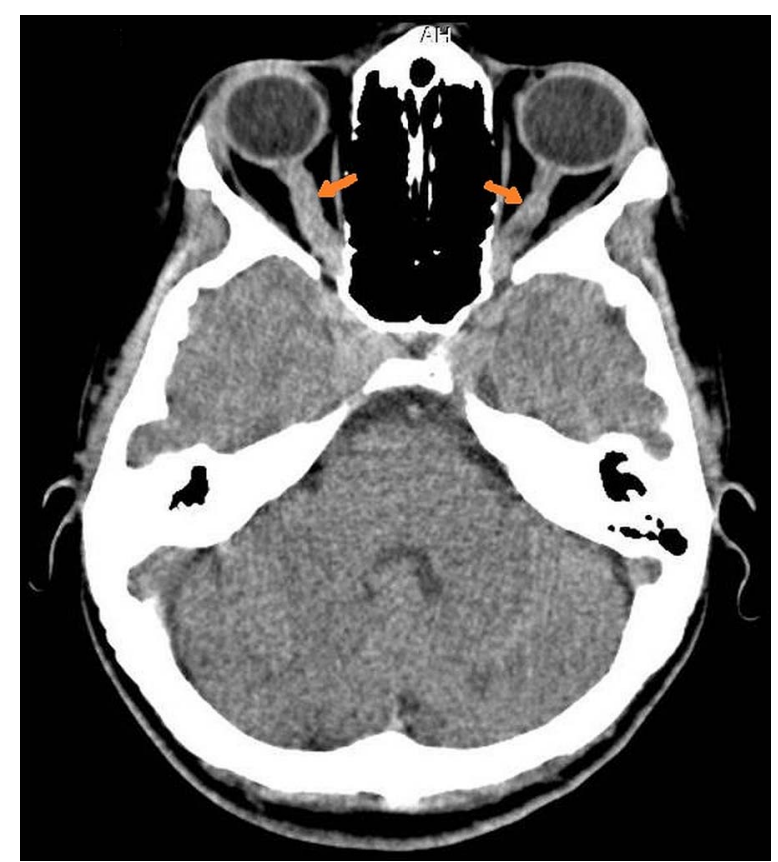

Figure 4 Cranial CT scan revealing bilateral thickening of the optic nerves (arrows), suggesting the presence of optic gliomas.

\section{Learning points}

- Neurofibromatosis type 1 (NF1) is an autosomal dominant disease, mainly characterised by the presence of 'café-au-lait' spots and neurofibromas (dermal being the most common). ${ }^{2}$

- NF1 can have cardiovascular, ophthalmological and osteoarticular manifestations, including kyphoscoliosis (occurring in approximately $10 \%$ of the cases), short stature and sphenoid wing dysplasia. The association of typical skin manifestations should suggest the diagnosis and prompt appropriate investigation. ${ }^{3}$

- There is no effective medical treatment to prevent or reverse the characteristic lesions of NF1, but an early diagnosis allows genetic counselling and early detection of treatable complications.

Competing interests None.

Patient consent Obtained.

Provenance and peer review Not commissioned; externally peer reviewed.

\section{REFERENCES}

1 [No authors listed]. Neurofibromatosis. Conference statement. National Institutes of Health Consensus Development Conference. Arch Neurol 1988;45:575-8.

2 Friedman JM. Neurofibromatosis 1: clinical manifestations and diagnostic criteria. J Child Neurol 2002;17:548-54; discussion 71-2.

3 Ferner RE, Huson SM, Thomas N, et al. Guidelines for the diagnosis and management of individuals with neurofibromatosis 1. J Med Genet 2007;44:81-8. 
Copyright 2015 BMJ Publishing Group. All rights reserved. For permission to reuse any of this content visit http://group.bmj.com/group/rights-licensing/permissions.

BMJ Case Report Fellows may re-use this article for personal use and teaching without any further permission.

Become a Fellow of BMJ Case Reports today and you can:

- Submit as many cases as you like

- Enjoy fast sympathetic peer review and rapid publication of accepted articles

- Access all the published articles

- Re-use any of the published material for personal use and teaching without further permission

For information on Institutional Fellowships contact consortiasales@bmjgroup.com

Visit casereports.bmj.com for more articles like this and to become a Fellow 